\title{
The story behind the upheaval after Niu FM hit the airwaves
}

\author{
TAPU MISA
}

New Zealand Herald columnist

The BIGGEST story in New Zealand's Pacific Island community in June network by the trust that the Government had appointed to fund it. It came after months of acrimony that began almost from the moment that Niu FM hit the airwaves.

As it happens, it is a story that I am intimately acquainted with. I have been watching this continuing saga since it began and was allowed to fester. Not only do I know the major players on both sides of the story - not surprising in a community as small as ours - but I feel like the network is a baby whose birth I witnessed.

Back in August 2002, when Niu FM scrambled to meet its contractual obligation to get on air five weeks from the day it signed the contract, I called on broadcasting contacts to find staff - not easy when you consider how scarce trained and experienced Pacific Island broadcasters are. They are an even rarer breed than trained PI journalists, which is why I also helped out in the newsroom in the network's early days.

I didn't charge for my services. This was not because of my selfless devotion to Pacific Island broadcasting, but because I was married to the then boss of the network and it didn't seem kosher to bill them for the privilege.

That is my dilemma in all this. I am the journalist best placed to write this article but because of that family connection, I have been confined to sitting back and watching the mainstream and even some of our own Pacific media make a meal of it. 
That is understandable up to a point; it is a complex story. To do it justice, journalists needed to be well acquainted with the local Pacific community, and with the history of Pacific broadcasting in this country as well as broadcasting generally. They needed to have a decent grasp of accepted business practice, how Government and its agencies contract out services, and the distinction between governance and management.

It boils down to a conflict between two trusts. One is completely owned and driven by Auckland's Pacific Island community and has been running a successful pan-Pacific radio station for 10 years. It is APICRT - the Auckland Pacific Island Community Radio Trust. Its 16 trustees are elected two-yearly by their communities. The other is the smaller, but more powerful, group of people (six at last count) whom the Government appointed in early 2002 to oversee the new national radio network for Pacific people. It is NPRT - the National Pacific Radio Trust.

Until last year, APICRT was concerned solely with the running of its Auckland station, Radio 531pi. But in 2002, the community trust won the contract to run New Zealand's first national radio network for Pacific Islanders, which became known as Niu FM. As the only contender with a track-record in pan-Pacific broadcasting, and the only community-owned outfit, 531pi had seemed like the obvious and only choice.

For those who had battled for years to keep the station going, it had seemed like a dream come true. Unfortunately for them, the dream turned out to be a double-edged sword. The station which pioneered pan-Pacific broadcasting had needed its wits to survive in what is widely acknowledged as the world's most competitive radio market. There were times early on, when it seemed that it might not make it. On one such occasion, when staff and management had to take pay cuts to ensure the station's survival, they joked grimly that if the money was any lower, they'd end up paying for the privilege of working there.

But it held on, delivering a mix of community, social and commercial programmes to Auckland's Pacific communities - Samoa, Tonga, Cook Islands, Tokelau, Niue, Tuvalu, Fiji and the Solomon Islands. In 10 years, it has developed from a station struggling on annual New Zealand on Air funding of $\$ 125,000$ to one which, for the last two years, has earned more than $\$ 1$ million in advertising income. It did not do this by being imprudent with its money, or by paying its management or trustees big money.

In fact, many of the people who have worked for Radio 531pi, from those who put out the station's Pacific language community programmes to the 
directors of the board, had done so for many years without ever being paid. Among them, directors such as Arthur Anae, a Samoan businessman and former National Party MP, who has been a stalwart of the station. James Prescott, a Tongan, who holds a number of other directorships, has a masters degree with honours in Accounting and Finance from Auckland University, and is a senior lecturerat the Auckland University of Technology. And there is Brian Chamberlin, current chairman of the board at Radio 531pi, a former president of Federated Farmers and the past chairman of the Radio Pacific board. Though not a Pacific Islander, he is so committed to the idea of a Pacific voice in broadcasting that he has given many years of his expertise and time to 531pi without ever being paid.

Many others have also given their time to the station. Only in the last few months have the Radio 531pi trustees been paid anything, and it is less than they would get on a school board of trustees. In 10 years of service, they have received a fraction of what the Government-appointed National Pacific Radio Trust members have been paid in a few short months. In fact, since NPRT took over running the network, the chairman, Simativa Perese, a barrister, has asked the Government for more money. He has been given an extra $\$ 40,000$ for himself - including $\$ 30,000$ for providing legal services to the trust. The other five trust members have also had their honorariums bumped up this year to just under $\$ 20,000$ each. One of them, Sina Moore, whose background is in sales and marketing, has also been paid the equivalent of $\$ 80,000$ a year for 'project management services', according to papers received from the Ministry of Culture and Heritage.

So, it was ironic that in the days after their contract was cancelled, it should be the Radio 531pi trustees and directors who would find themselves accused of profligate spending, of having their noses in the Government trough, of misusing taxpayer funds. That this should happen to people who had given more to Pacific Island broadcasting - and received less - than anyone I knew seemed the height of injustice.

I was at the launch in Mangere on August 31, when the network crackled to life, delivered by a small and sweaty bunch of Radio 531pi staff who had laboured long hours to make the on-air date, while Members of Parliament, Government officials and the network's trust members made fine speeches to the assembled gathering about what the network would mean to Pacific people in Auckland, Wellington and Christchurch.

The Government had committed nearly $\$ 8$ million to the three-year pilot. 
Radio 531pi's newly set up sister company, Pasefika Communications Network Ltd, was the network's provider. The NPRT was to look after the funds and keep a governing eye on proceedings. It was touted as a momentous breakthrough for New Zealand's Pacific communities. But it was not long before relations between the two trusts broke down. Soon, the goodwill that was on show back in August was a distant memory. In October, barely a month after its launch, the Government trust was already publicly alleging 'material breaches' on the part of Pasefika, and was threatening to cancel the contract. By November, the two groups were in mediation.

At issue, were the so-called 'material breaches', and Simativa Perese's attempt to install Sina Moore as the full-time managing director of Pasefika. Pasefika resisted, claiming undue and unreasonable interference by the trust. With the help of a QC, Ailsa Duffy, it won what it thought was the right to get on with running the network. But despite the mediation outcome (which set Pasefika back $\$ 30,000$ in legal fees), nothing changed. The Government trust continued to allege material breaches.

On 3 June 2003, Pasefika was unceremoniously sacked as the provider of Niu FM. One moment they were on air, broadcasting from the old Otahuhu District Court building which housed their studios, and the next the switch had been pulled on them. Without missing a minute of air time, NPRT had taken control of Niu FM, and begun broadcasting from studios in the upmarket Auckland suburb of Ponsonby. It had taken the frequency, and by the week's end, most of the staff. The trust hired a high-powered Wellington public relations firm to explain why it had taken the rather dramatic step of dumping Pasefika Communications just nine months into its contract, and despite every indication that it was doing a good job.

Niu FM was popular, advertising was increasing monthly, and audience surveys after only seven months showed the network was doing better than many more established stations, even in the over-heated Auckland market where it was already rating in the top third. Most importantly, it was winning its required market - Pacific Islanders aged 20-40 - which flew in the face of NPRT's claims that the network's programming wasn't delivering to the Pacific Island community. In an article in Metro (September 2003, p 104), Simativa Perese claims, for example, that Niu FM's news team failed to cover important Pacific Island issues. 'It didn't cover anything,' he's quoted as saying, and refers specifically to the station's failure to address the issue of tithing.

The claim is extraordinary. The news team of four was headed by Bob 
Wandstraat, a journalist with long experience in newspapers and radio who also tutored the Manukau Polytechnic journalism course for Pacific Island students back in the late 1980s. And among the many issues that Wanstraat and his team covered in their nine months was... tithing. Not just once but repeatedly (and yes, Wandstraat still has the tapes). Which begs the question: Did Perese actually listen to the network he was so determined to criticise?

There were other more damaging claims. In the days following the contract cancellation, much was made of Pasefika's so-called misspending of taxpayer funds. Perese's trust cited the purchase of a couple of company cars (Pasefika replied that these were part of employment contracts for two staff members, including Niu FM's highly popular announcer Oscar Kightley); drinks and dinner at a local bar and Vietnamese restaurant (to thank staff for their hard work in getting the network to air in record time, said Pasefika, and which, contrary to the figure quoted in Metro ( $\mathrm{p} 105$ ), did not cost \$12,000, but around \$2500); and the purchase of tickets for the network's advertisers to watch one of the America's Cup races (an advertising promotion, said Pasefika, normal practice for a network required to earn advertising revenue as part of its contract).

The community trust was also accused of using taxpayer money to benefit its Radio 531pi operation, and criticised for trying to minimise Niu FM's impact on 531pi. Both were broadcasting in the Auckland market, and needed to be managed carefully to ensure the continued survival of one, and the growth of the other. This seemed entirely reasonable to APICRT, but the National Pacific Radio Trust regarded any consideration of 531pi's interests as a gross breach.

But very little of the community trust's side of the story got through a mainstream media accustomed to stories of 'brown failure', however unjustified. It was all too easy to dismiss this as just another example of an unprofessional community group which had got in over its head. No one seemed much interested in the track record of a group of people who, in a decade of dealing with the funding agency, NZ on Air, and operating exactly as they had done with Niu FM, had never had their reputations or integrity called into question.

Amid all the claims and counter-claims, there was only one absolute certainty: the relationship between those who ran the community radio trust and the Government's representatives was beyond repair. The reason, according to APICRT, was the failure of the National Pacific Radio Trust to understand the difference between the governance role of a funder and the management role of the provider. In fact, it said, the Government trust had acted from the start as if it were the provider, and had insisted on 'micro-managing' the project to such 
an extent that it had made it impossible for Pasefika to do its job. An example of this was Perese's attempt to force Sina Moore's appointment as managing director of Pasefika - a move which was unprecedented for a Government entity charged with funding responsibilities.

Consultant Peter McKinlay is a former Treasury official who has seen many Government contracts fail through lack of governance skills. He was asked by the community trust to look at their contract with the NPRT, and specifically at the trust deed drawn up by Perese and his fellow trustees - after the contract was signed. McKinlay (who became an expert witness for Pasefika) concluded that the deal was fatally flawed. It was doomed to fail - and the crux of the problem lay in the 'unusual' trust deed that gave all the power to the Government trust, while providing no protection to Pasefika (or indeed anyone else who might have gone into business with them). Whether or not the trust deed should even be part of the agreement between the two parties is one of the points of contention yet to be argued at the High Court.

The debacle raises questions, too, about the Government's failure to adequately monitor contracts intended to deliver its social objectives. In this case, it had appointed a group of people with the right ethnic profile but little corporate governance experience (Perese, despite impressive legal qualifications and some experience as a radio announcer, has none) and then left them to draw up an agreement giving themselves unprecedented power.

Despite many attempts by APICRT trustees to get officials and ministers to intervene on their behalf, or to hear their side of the story, the Government has been determinedly deaf. Even in the early days of the dispute, it seemed to have its mind made up. Back in November 2002, disbelieving community trustees listened to Mark Gosche, then minister of Pacific Island Affairs, present them with two options for solving the problem. Both options effectively handed the reins - and the contract - to the NPRT. Pasefika would quietly disappear into the ether, losing a contract that it had won fairly and at considerable cost to itself - and with absolutely no suggestion that they would be compensated for their losses. The community trustees had no hesitation in unanimously rejecting the proposals - but that didn't stop the NPRT from continuing to put them on the table, right up until the cancellation.

It is clear that the National Pacific Radio Trust's takeover of the network has been costly, but it is difficult to get a clear picture of just how much extra has been spent. The trust has been able to use its charitable status so far to avoid the degree of public scrutiny that is expected of other Government agencies. Unlike 
the community owned Pasefika and 531pi, which are accountable to their communities, NPRT is accountable only to its political masters.

The Government, meanwhile, is unlikely to break ranks with a group of people that it appointed, no matter how badly they might manage the network, or how much extra money it might need to plough into the project as a result of the trust's stewardship. That is a shame. In September 2003, the two trusts square up at the High Court in Auckland - an expensive, nasty business that could have been avoided if the Government had exerted itself a little more vigorously, and in a more even-handed manner, on behalf of the Pacific Island community. What is at stake here is not only the future of Pacific broadcasting but exactly the kind of community-driven initiative that this Labour Government is supposed to support. The $\$ 7.7$ million that is funding the network was set aside to do what the Government calls 'capacity building' - as the name implies, it was aimed at building up existing Maori and Pacific Island organisations, transforming them from shoestring operations to fully competitive businesses.

That is why the Niu FM network was built on top of Radio 531pi, using its staff, resources and a decade of know-how and experience in pan-Pacific broadcasting. And why the network's programming is cloned on the 531pi model. It was 531 pi expertise and experience which officials used to develop the case that convinced the Government to put capacity building money into the network.

Radio 531 pi's trustees always knew that they were putting the station at risk, particularly if the Government stopped funding the pilot. But it beggars belief that they should now stand accused of running the two stations so as to ensure the continued survival of both. Having given birth to the new network, and promoted it vigorously, Radio 531pi now finds itself in an even worse position than it was before the contract. It is now up against a well-funded competitor which has transplanted its staff, duplicated its music and programming, and which is now being run by the Government trust that was appointed to fund it.

Had Radio 531pi's trustees known that this was what the Government meant by 'capacity building', they would never have bought into it.

Tapu Misa is a freelance writer and columnist of The New Zealand Herald. She is married to Sefita Hao'uli, one of the founders of Radio 531pi, and the former interim manager of Niu FM.

taputapu@paradise.net.nz 